\title{
Climate change and polar range expansions: Could cuttlefish cross the Arctic?
}

\author{
José C. Xavier ${ }^{1,2}$, Lloyd S. Peck ${ }^{1}$, Peter Fretwell ${ }^{1} \&$ John Turner ${ }^{1}$
}

\section{1- British Antarctic Survey, Natural Environment Research Council, High Cross, Madingley Road, CB3} 0ET Cambridge, UK

2- Marine and Environmental Science Centre (MARE), Faculdade de Ciências e Tecnologia, Universidade de Coimbra, Departamento das Ciências da Vida, Coimbra, PT

\section{Abstract}

Climate change can have major effects on the distribution of species. In marine ecosystems, the cold waters of the Arctic have restricted warmer water species from crossing between Eurasia and North America. However, with Arctic waters becoming warmer, various marine species have expanded their distribution. Cuttlefish are fast growing, voracious predators and are absent in American waters. The European cuttlefish Sepia officinalis is the most northerly-distributed cuttlefish, with potential to expand its range and cross to the American continent, potentially causing changes in shelf food webs. Climate model predictions suggest that the $S$. officinalis could potentially reach American shores, by 2300 via the north Atlantic with medium mitigation of greenhouse gas concentrations; we predict that adult dispersal of cuttlefish across the Atlantic sector would require a migration distance of over $1400 \mathrm{~km}$ at depths below $200 \mathrm{~m}$ and temperatures above $7^{\circ} \mathrm{C}$ (temperature below which cuttlefish can not maintain routine metabolic processes physiologically). For temperatures above $9.5^{\circ} \mathrm{C}$ (temperature above which cuttlefish can grow), $2500 \mathrm{~km}$ would be required, and such conditions will possibly exist by the year 2300 . If they reach American shores they could have large impacts on coastal marine ecosystems, due to their wide diet (e.g. diet covers many shallow water crustacean and fish species) and its potential as prey, and due to their short life history strategy of "live fast, die young".

KEYWORDS: Invasion, Polar, predator, cephalopod, distribution - Climate change - Sepia officinalis 


\section{INTRODUCTION}

Global warming is producing significant changes in marine ecosystems. Emerging evidence suggests that marine organism distributions may respond more rapidly to climate change than those on land, despite slower oceanic warming (Richardson and Poloczanska 2008; Kortsch et al. 2015). Range shifts of hundreds of kilometres in a few decades have been observed in various organisms, such as phytoplankton, zooplankton and fish (Beaugrand et al. 2002). However, studies have rarely investigated fast growing, carnivorous species with the potential for also marked impacts on new habitats. The short generation times of coastal cuttlefish, squid and octopods might enable them to adjust faster to changing environmental conditions than those with slow growth and late maturity (Boyle and Rodhouse 2005; Xavier et al. 2015). Indeed, the short life span and generation time of shallow water cephalopods has been suggested to enable a proportion of each new generation to actively avoid or exploit localised warming events (Rodhouse 2013). Some studies already investigated range shifting in Octopods, such as Octopus tetricus (Ramos et al. 2014) at the southerly extension of the warm East Australian Current, showing that this octopod maintains a fast growth rate (under warming conditions), high rate of population turnover, small body size and a short life span at the leading edge of their range extension. In squid, such as Dosidicus gigas (Zeidberg and Robison 2007; Ruiz-Cooley et al. 2013), Sepietta oweniana, Todarodes sagittatus, Todaropsis eblanae and Teuthowenia megalops (Golikov et al. 2013; Golikov et al. 2014), range expansion has been attributed to changes in climate-linked oceanographic conditions (e.g. warming waters), a reduction in competing top predators and/or of a decline in abundance of a commercial groundfish species. However, unlike octopods and squid, cuttlefish Sepia spp. do not occur in the Americas or Polar regions (Boletzky 1983 ; Xavier et al. 1999; Xavier and Cherel 2009; Rodhouse et al. 2014). Nearly 115 sepiid species are described inhabiting shallow tropical/temperate waters of AfroEurasia, along the coasts of the East Atlantic, Indian and West Pacific (Reid et al. 2005).The question arises: as the Arctic warms when will environmental conditions allow cuttlefish to cross the Arctic and reach American coastal waters?

\section{FACTORS AFFECTING CUTTLEFISH DISTRIBUTION}

Here, we focus our discussion on the European cuttlefish, S.officinalis, and the potential range expansion of the species to America via Europe. The route via the Bering Sea (i.e. Asia - America route) 
is not discussed further in this study because there are no published studies on the temperature tolerance of Sepia kobiensis (the most northern cuttlefish species distributed in the north Pacific) (Reid et al. 2005) nor any other North Pacific, cold-adapted cuttlefish species to support such hypotheses. However, due to the shallow waters between Asia and the Americas, via the Bering Sea, the dominating W-E currents could aid such range expansion of cuttlefish.

The most northerly distributed cuttlefish worldwide is Sepia officinalis (Family Sepiidae, Order Sepiida, Class Cephalopoda) at around $62^{\circ} \mathrm{N}$ in European waters, a well known opportunistic and voracious marine predator that can reach large size (up to 4-kg), and feeds on a wide range of prey (Reid et al. 2005). Physiologically, S. officinalis cannot maintain routine metabolic processes at temperatures $\leq 7^{\circ} \mathrm{C}$, grows positively from water temperatures above $9.5^{\circ} \mathrm{C}$ and spawning peaks at $13-15^{\circ} \mathrm{C}$ (Boletzky 1983 ; Pimentel et al. 2012). Temperature has large effects on development is this species. When eggs are exposed to warming conditions $\left(13\right.$ to $\left.19^{\circ} \mathrm{C}\right)$, oxygen consumption increases throughout embryogenesis. At $15^{\circ} \mathrm{C}, 41 \%$ of the egg yolk is used for growth, and only $10 \%$ is used for catabolic processes, whereas at higher temperatures $\left(24^{\circ} \mathrm{C}\right)$ yolk utilisation for growth is only $15 \%$, but $52 \%$ is for catabolism, resulting in small hatchling size (Bouchaud 1991). S. officinalis is thus well adapted to cool temperate conditions and it has been suggested that, with warming, S. officinalis may lay their eggs in warmer and deeper environments (Pimentel et al. 2012). S. officinalis is, however, limited to a depth of 150-200 $\mathrm{m}$ as the chambers in the cuttlebone, the calcified internal shell, can implode beyond these depths (Ward and Boletzky 1984). Other cuttlefish species at lower latitude and warmer sites, on the other hand, can be found up to $1000 \mathrm{~m}$ deep, and may be better adapted to pressure. Sepia elegans, for example is found up to $60^{\circ} \mathrm{N}$ in depths of $500 \mathrm{~m}$, and Sepia orbignyana up to $54^{\circ} \mathrm{N}$ in depths of $570 \mathrm{~m}$ (Reid et al. 2005).

Cuttlefish today are absent from the Americas, but this is probably not due to lack of habitat (Young et al. 1998), as potential prey are abundant. In fact, Sepia officinalis has been cultured during multiple generations in American laboratories where they have been fed with live local crustaceans and fish (Forsythe et al. 2002). One reason for their absence, appears to be low temperature in the Arctic and the depth/distance barriers of the other ocean basins, combined with the time of formation of these barriers (Young et al. 1998). The shallow-water tropical bridge between Africa and South America was severed in the late Cretaceous, leaving the northern rim of the Atlantic Basin as the only possible migration route for shallow demersal organisms between Europe and the Americas after this time. During the early Cenozoic (Palaeocene and Eocene), a series of radiations began in the warm Tethys Sea that resulted in the broad colonization of the Belosaepiidae (a cephalopod family known from the Eocene, closely similar to cuttlefish) (Khromov 1998). Migration across the Atlantic was possible around the top of the basin, 
where temperatures were tolerable. After the Belosaepiidae became extinct in the Oligocene, cuttlefish species emerged in Europe (North East Atlantic), the only location of fossils currently known (Young et al. 1998). Their distribution was, however, restricted by the colder conditions during this period, preventing colonisation across the North Atlantic as utilised by the Belosaepiidae.

Cuttlefish are also absent from the Antarctic, which is likely due to cold conditions and the deep water barriers between Antarctica and the other land masses, that were completed with the formation of the Drake Passage around 30-50 million years (Ma) ago (Livermore et al. 2005). There are cephalopod fossils in the Antarctic, from belemnites and Mesozoic teuthids (Doyle 1991), but none from the family Sepiidae probably due to the absence of marine Tertiary sediments (Dirk Fuchs, Freie Universität Berlin, pers. comm.). The sepiids closest to the Antarctic are in Australian waters, at $42^{\circ} \mathrm{S}$, but a lack suitable habitat further south (Reid et al. 2005).

The northern expansion of S.officinalis appears to be mainly limited by physiology, but life cycle constraints and habitat availability may also play a part. Eggs of this species, as for all sepiids, are large and attached to hard substrata in depths usually less than $50 \mathrm{~m}$, producing benthic hatchlings with limited dispersal capacity. Lifespan is $18-24$ months and dispersal is predominantly via sub-adult and adult migration (Reid et al. 2005). As cuttlefish spawning appears restricted to shallow depths, iceberg scouring might also limit their ability to colonise low temperature areas by restricting areas of suitable habitat to attach eggs to algae and hard substrata. If waters warmed, S. officinalis could potentially expand its northern range edge via two routes: either along the $200 \mathrm{~m}$ shelf towards the Arctic, and/or via the Faroe Islands - Iceland - Greenland to north Canada over deeper waters (Fig. 2), both aided by surface currents (Straneo and Heimbach 2013) that could transport adult cuttlefish (as they expand north) and/or, for example, rafting with marine (floating) debris (e.g. broken kelp, floating old fishing gear or plastic material initially at the bottom) (as cuttlefish eggs) (Boletzky 1983; Arkley et al. 1996; Blanc and Daguzan 1998; Sykes et al. 2014). Although cuttlefish are benthopelagic organisms, they are known to also swim into the water column (Okutani 1990), which could be transport them further north by currents. Furthermore, if these adults can reach Faroe Islands, Iceland, Greenland and North Canada, they would be able to reproduce and attach their eggs to available algae (e.g. sea grass or kelp) (Kjellman 1883; Mann 1973; Arkley et al. 1996; Short et al. 2007). This would permit a sequence of generations to allow the establishment of cuttlefish in these regions.

Depth may not be a total barrier for cuttlefish expansion, as between South Africa and Mauritius (Mascarene Ridge), the same cuttlefish species (Sepia vermiculata) occurs in both places, although separated by deep waters (Reid et al. 2005). If cuttlefish cross the Arctic, their life history characteristics 
would potentially allow them to adapt quickly and spread rapidly. A further consideration is that the aquarium industry might provide another colonisation or invasion route, as cuttlefish are readily available in the USA as pets. If released in the sea, under the right conditions, they could flourish, as has occurred for other invaders (Gido and Brown 1999).

\section{PREDICTING THE NORTHERN RANGE EXPANSION OF S. OFFICINALIS}

How much do Arctic waters need to warm for cuttlefish to cross the Arctic? As S. officinalis is the most abundant, largest and the most known northerly distributed cuttlefish, we use this species as the candidate for exploring the likelihood of range expansion. The total reported annual landings of cuttlefish in Europe range from 35000 to 41000 tons, showing that a considerable population exists in European waters (Pierce et al. 2010). Recent Arctic Ocean warming is thought to be closely connected with increased heat content of the Atlantic water masses with a $1.3^{\circ} \mathrm{C}$ increase in annual water temperatures from 1990 to 2005 (Walczowski and Piechura 2006).

An expected migration route for S. officinalis across the Arctic would be from northern Europe via Iceland to North America (Fig. 1). Based on the HadGEM2-ES model (Hadley Centre Global Environmental Model version 2 Earth System configuration) with medium mitigation of greenhouse gas concentrations (following the "Representative Concentration Pathway" RCP4.5) (Caesar et al. 2013), we predict that adult dispersal of cuttlefish across the Atlantic sector would require a migration of over 1400 $\mathrm{km}$ at depths deeper than $200 \mathrm{~m}$ and temperatures above $7^{\circ} \mathrm{C}$. For temperatures above $9.5^{\circ} \mathrm{C}, 2500 \mathrm{~km}$ would be required, and such conditions will possibly exist by the year 2300 (See supplementary material).

Increasing temperatures may facilitate a range expansion of cuttlefish to the Arctic, but climate change may also bring environmental challenges such as ocean acidification. Polar marine calcifying organisms may be amongst the first affected by ocean acidification-driven changes in marine carbonate chemistry (Orr et al. 2005). In cuttlefish laboratory experiments with S. officinalis reported higher cuttlebone calcification associated with decreasing pH (Dorey et al. 2013). This hyper-calcification would likely change the cuttlebone buoyancy, and possibly change the implosion resistance of this structure. However, the behavioural or ecological significance of these changes are still unknown. When compared with other organisms, Perry et al. (2005) showed that the distributions of both exploited and nonexploited fish species have responded markedly to recent increases in sea temperature, with nearly twothirds of species shifting in mean latitude or depth over 25 years. Furthermore, most of the fish species that shifted their distributions had faster life cycles (but still slower than cuttlefish) and smaller body 
sizes. Temperature rises are likely to have profound impacts on community interactions through continued shifts in distribution of marine organisms (Perry et al. 2005), particularly those that are fast growing, with short life cycles and a broad range of prey.

In summary, the cuttlefish Sepia officinalis is one of the marine organisms that, under a favourable climatic scenario and conditions (e.g. by currents, cross over deep regions), may be able to cross the Arctic region and occupy a niche in the marine ecosystems of the American continent. Due to its fast growth and metabolism, typical of cephalopods, cuttlefish may be able to occupy an ecological niche rapidly.

\section{ACKNOWLEDGEMENTS}

We thank Roger Villanueva for the numerous discussions and contributions to previous drafts and Tom Bracegirdle, Dan Jones, Alexey Golikov and Emma Boland for advice on polar oceanography. This research is part of the SCAR AnT-ERA and ICED programs. JX is supported by the Investigator FCT program (IF/00616/2013).

\section{References}

Arkley K, Jacklin MS, Boulter M, Tower J (1996) The cuttlefish (Sepia officinalis): A guide to its exploitation in UK waters, Seafish Report N. SR467. Sea-fish Industry Authority, Hull, UK

Beaugrand G, Reid PC, Ibañez F, Lindley JA, Edwards M (2002) Reorganization of North Atlantic marine copepod biodiversity and climate. Science 296: 1692

Blanc A, Daguzan J (1998) Artificial surfaces for cuttlefish eggs (Sepia officinalis L.) in Morbihan Bay, France. Fish Res 38: 225-231

Boletzky SV (1983) Sepia officinalis. In: Boyle PR (ed) Cephalopod life Cycles. Academic Press, London, pp 31-52

Bouchaud O (1991) Energy consumption of the cuttlefish Sepia officinalis (Mollusca: Cephalopoda) during embryonic development, preliminary results. Bull of Mar Sci 49: 333-340

Boyle P, Rodhouse PG (2005) Cephalopods ecology and fisheries. Blackell Science, Oxford

Caesar J, Palin E, Liddicoat S, Lowe J, Burke E, Pardaens A, Sanderson M, Kahana R (2013) Response of the HadGEM2 Earth System Model to Future Greenhouse Gas Emissions Pathways to the Year 2300. J Climate 26: 3275-3284

Dorey N, Melzner F, Martin S, Oberhänsli F, Teyssié JL, Bustamante P, Gattuso JP, Lacoue-Labarthe T (2013) Ocean acidification and temperature rise: effects on calcification during early development of the cuttlefish Sepia officinalis. Mar Biol 160: 2007-2022

Doyle P (1991) Teuthid cephalopods from the upper Jurassic of Antarctica. Palaentology 34: 169-178 Forsythe J, Lee P, Walsh L, Clark T (2002) The effects of crowding on growth of the European cuttlefish, Sepia officinalis Linnaeus, 1758 reared at two temperatures. J Exp Mar Biol and Ecol 269: 173-185

Gido KB, Brown JH (1999) Invasion of North American drainages by alien fish species. Freshw Biol 42: 387-399 Golikov AV, Sabirov RM, Lubin PA, Jørgensen LL (2013) Changes in distribution and range structure of Arctic cephalopods due to climatic changes of the last decades. Biodiversity 14: 24-35

Golikov AV, Sabirov RM, Lubin PA, Jørgensen LL, Beck I-M (2014) The northernmost record of Sepietta oweniana (Cephalopoda: Sepiolidae) and comments on boreo-subtropical cephalopod species occurrence in the Arctic. Mar Biodiversity Records 7: e58 
Khromov DN (1998) Distribution patterns of Sepiidae. In: Voss NA, Vecchione M, Toll RB, Sweeney MJ (eds) Systematics and biogeography of cephalopods. Smithson Contr Zool, pp 191-206

Kjellman FR (1883) The algae of the Arctic Sea: A survey of the species, together with an exposition of the general characters and the development of flora. P. A. Norstedt ans Soner, Stockholm

Kortsch S, Primicerio R, Fossheim M, Dolgov AV, Aschan M (2015) Climate change alters the structure of arctic marine food webs due to poleward shifts of boreal generalists. Proc R Soc B 282: 20151546

Livermore R, Nankivell A, Eagles G, Morris P (2005) Paleogene opening of Drake Passage. Earth and Planetary Letters 236: 459-470

Mann KH (1973) Seaweeds: their productivity and strategy for growth. Science 182: 975-981

Okutani T (1990) Squids, cuttlefish and octopuses. Mar Behav and Physiol 18: 1-17 doi 10.1080/10236249009378778

Orr JC, Fabry VJ, Aumont O, Bopp L, Doney SC, Feely RA, Gnanadesikan A, Gruber N, Ishida A, Joos F, Key RM, Lindsay K, Maier-Reimer E, Matear R, Monfray P, Mouchet A, Najjar RG, Plattner G-K, Rodgers KB, Sabine CL, Sarmiento JL, Schlitzer R, Slater RD, Totterdell IJ, Weirig M-F, Yamanaka Y, Yool A (2005) Anthropogenic ocean acidification over the twenty-first century and its impact on calcifying organisms. Nature 437: 681-686

Perry AL, Low PJ, Ellis JR, Reynolds JD (2005) Climate Change and Distribution Shifts in Marine Fishes. Science 308: 1912-1915

Pierce GJ, Allcock AL, Bruno I, Bustamante P, González A. F, Guerra A, Jereb P, Lefkaditou E, Malham SK, Moreno A, Pereira J, Piatkowski U, Rasero M, Sánchez P, Santos MB, Santurtun M, Seixas S, Sobrino I, Villanueva R (2010) Cephalopod biology and fisheries in Europe. International Council for the Exploration of the Sea, Copenhagen

Pimentel MS, Trubenbach K, Faleiro F, Boavida-Portugal J, Repolho T, Rosa R (2012) Impact of ocean warming on the early ontogeny of cephalopods: a methabolic approach. Mar Biol 159: 2051-2059

Ramos JE, Pecl GT, Moltschaniwskyj NA, Strugnell JM, León RI, Semmens JM (2014) Body size, growth and life span: implications for the polewards range shift of Octopus tetricus in south-eastern Australia. PLoS ONE 9: e103480

Reid A, Jereb P, Roper CFE (2005) Family Sepiidae. In: Jereb P, Roper CFE (eds) Cephalopods of the world An annotated and illustrated catalogue of species known to date. FAO Species Catalogue for Fishery Purposes. Rome, FAO, pp 57-152

Richardson AJ, Poloczanska ES (2008) Ocean Science: under-resourced, under threat. Science 320: 1294-1295 Rodhouse PG (2013) Role of squid in the Southern Ocean pelagic ecosystem and the possible consequences of climate change. Deep Sea Res II 95: 129-138

Rodhouse PG, Xavier JC, Griffiths H (2014) Southern Ocean squid. In: De Broyer C, Koubbi P, Griffiths H, Danis B, David B, Grant S, Gutt J, Held C, Hosie G, Huettmann F, Post A, Raymond B, Ropert-Coudert Y, van de Putte A (eds) The CAML / SCAR-MarBIN Biogeographic Atlas of the Southern Ocean. Scientific Committee on Antarctic Research, Cambridge, pp 284-289

Ruiz-Cooley RI, Ballance LT, McCarthy MD (2013) Range expansion of the jumbo squid in the NE Pacific: $\delta 15 N$ decrypts multiple origins, migration and habitat use. PloS one 8: e59651

Short F, Carruthers T, Dennison W, Waycott M (2007) Global seagrass distribution and diversity: A bioregional model. J Exp Mar Biol and Ecol 350: 3-20 doi http://dx.doi.org/10.1016/j.jembe.2007.06.012

Straneo F, Heimbach P (2013) North Atlantic warming and the retreat of Greenland's outlet glaciers. Nature 504: 36-43

Sykes AV, Domingues P, Andrade JP (2014) Sepia officinalis. In: Iglesias J, Fuentes L, Villanueva R (eds) Cephalopod Culture. Springer, pp 175-204

Walczowski W, Piechura J (2006) New evidence of warming propagating toward the Arctic Ocean. Geophys Res Lett 33: L12601

Ward P, Boletzky SV (1984) Shell implosion depth and implosion morphologies in three species of Sepia (Cephalopoda) from the Mediterranean Sea. J Mar Biol Ass UK 64: 955-966 
Xavier JC, Allcock L, Cherel Y, Lipinski MR, Gomes-Pereira JN, Pierce G, Rodhouse PGK, Rosa R, Shea L, Strugnell J, Vidal E, Villanueva R, Ziegler A (2015) Future challenges in cephalopod research. J Mar Biol Ass UK 95: 999-1015

Xavier JC, Cherel Y (2009) Cephalopod beak guide for the Southern Ocean. British Antarctic Survey

Xavier JC, Rodhouse PG, Trathan PN, Wood AG (1999) A Geographical Information System (GIS) atlas of cephalopod distribution in the Southern Ocean. Antarct Sci 11: 61-62

Young RE, Vecchione M, Donovan D (1998) The evolution of coleoid cephalopods and their present biodiversity and ecology. S Afr J Mar Sci 20 393-420

Zeidberg LD, Robison BH (2007) Invasive range expansion by the Humboldt squid, Dosidicus gigas, in the eastern North Pacific. Proc Nat Acad Sci 104: 12948-12950 
SUPPLEMENTARY MATERIAL. Distances across the Arctic from Europe to North America (upper) following the mean summer sea surface temperature contours of $7^{\circ} \mathrm{C}$ (limit for S. officinalis adult survival) and $9.5^{\circ} \mathrm{C}$ (limit for S. officinalis reproduction) as predicted by runs of the HadGEM2ES model using a medium mitigation run RCP4.5 (See methods in Caesar et al. 2013).

\section{Europe to North America}

(via Iceland)

\begin{tabular}{|c|c|c|c|c|}
\hline & $7^{\circ} \mathrm{C}$ & $7^{\circ} \mathrm{C}$ & $9.5^{\circ} \mathrm{C}$ & $9.5^{\circ} \mathrm{C}$ \\
\hline Year & $\begin{array}{l}\text { Distance } \\
(\mathrm{km}) \text { coast to } \\
\text { coast }\end{array}$ & $\begin{array}{l}\text { Distance }(\mathrm{km}) \text { to reach the } \\
200 \text { metre contour depth in } \\
\text { North America East coast }\end{array}$ & $\begin{array}{l}\text { Distance }(\mathrm{km}) \\
\text { coast to coast }\end{array}$ & $\begin{array}{l}\text { Distance }(\mathrm{km}) \text { to reach } \\
\text { the } 200 \text { metre contour } \\
\text { depth in North America } \\
\text { East coast }\end{array}$ \\
\hline 2012 & 2960 & 2530 & 3042 & 2530 \\
\hline 2020 & 2960 & 2530 & 3023 & 2530 \\
\hline 2030 & 2953 & 2530 & 2953 & 2530 \\
\hline 2040 & 2953 & 2530 & 2953 & 2530 \\
\hline 2050 & 2953 & 2530 & 2953 & 2530 \\
\hline 2060 & 2953 & 2530 & 2953 & 2530 \\
\hline 2070 & 2953 & 2439 & 2953 & 2530 \\
\hline 2080 & 2953 & 2439 & 2953 & 2530 \\
\hline 2090 & 2930 & 2388 & 2953 & 2530 \\
\hline 2100 & 2930 & 2064 & 2953 & 2530 \\
\hline 2110 & 2930 & 2062 & 2953 & 2530 \\
\hline 2120 & 2930 & 2008 & 2953 & 2530 \\
\hline 2130 & 2930 & 2008 & 2953 & 2530 \\
\hline 2140 & 2930 & 2008 & 2953 & 2530 \\
\hline 2150 & 2930 & 2008 & 2953 & 2530 \\
\hline 2160 & 2930 & 2008 & 2953 & 2530 \\
\hline 2170 & 2930 & 2008 & 2953 & 2530 \\
\hline 2180 & 2930 & 2008 & 2953 & 2530 \\
\hline 2190 & 2930 & 2008 & 2953 & 2530 \\
\hline 2200 & 2930 & 2008 & 2953 & 2530 \\
\hline 2210 & 2930 & 1932 & 2953 & 2530 \\
\hline 2220 & 2930 & 1781 & 2953 & 2530 \\
\hline 2230 & 2930 & 1718 & 2953 & 2530 \\
\hline 2240 & 2930 & 1487 & 2953 & 2530 \\
\hline 2250 & 2930 & 1487 & 2953 & 2530 \\
\hline 2260 & 2930 & 1469 & 2953 & 2530 \\
\hline 2270 & 2930 & 1430 & 2953 & 2530 \\
\hline 2280 & 2930 & 1430 & 2953 & 2530 \\
\hline 2290 & 2930 & 1430 & 2953 & 2530 \\
\hline 2300 & 2930 & 1430 & 2953 & 2530 \\
\hline
\end{tabular}




$$
\frac{M}{M}
$$


Figure 1. Mean summer sea surface temperatures (SST in ${ }^{\circ} \mathrm{C}$ ) for the present day and projected for 2300, for the North Atlantic (The "present SST" also includes the present distribution of Sepia officinalis; Eastern Atlantic, from the Shetland Islands and southern Norway south through the Mediterranean Sea to northwestern Africa up to Senegal (Reid et al. 2005)). Projections are based from runs of the HadGEM2-ES medium mitigation run (see text) and are for mean summer temperature covering a 3 month period. The $200 \mathrm{~m}$ depth contours is also shown in all panels. 


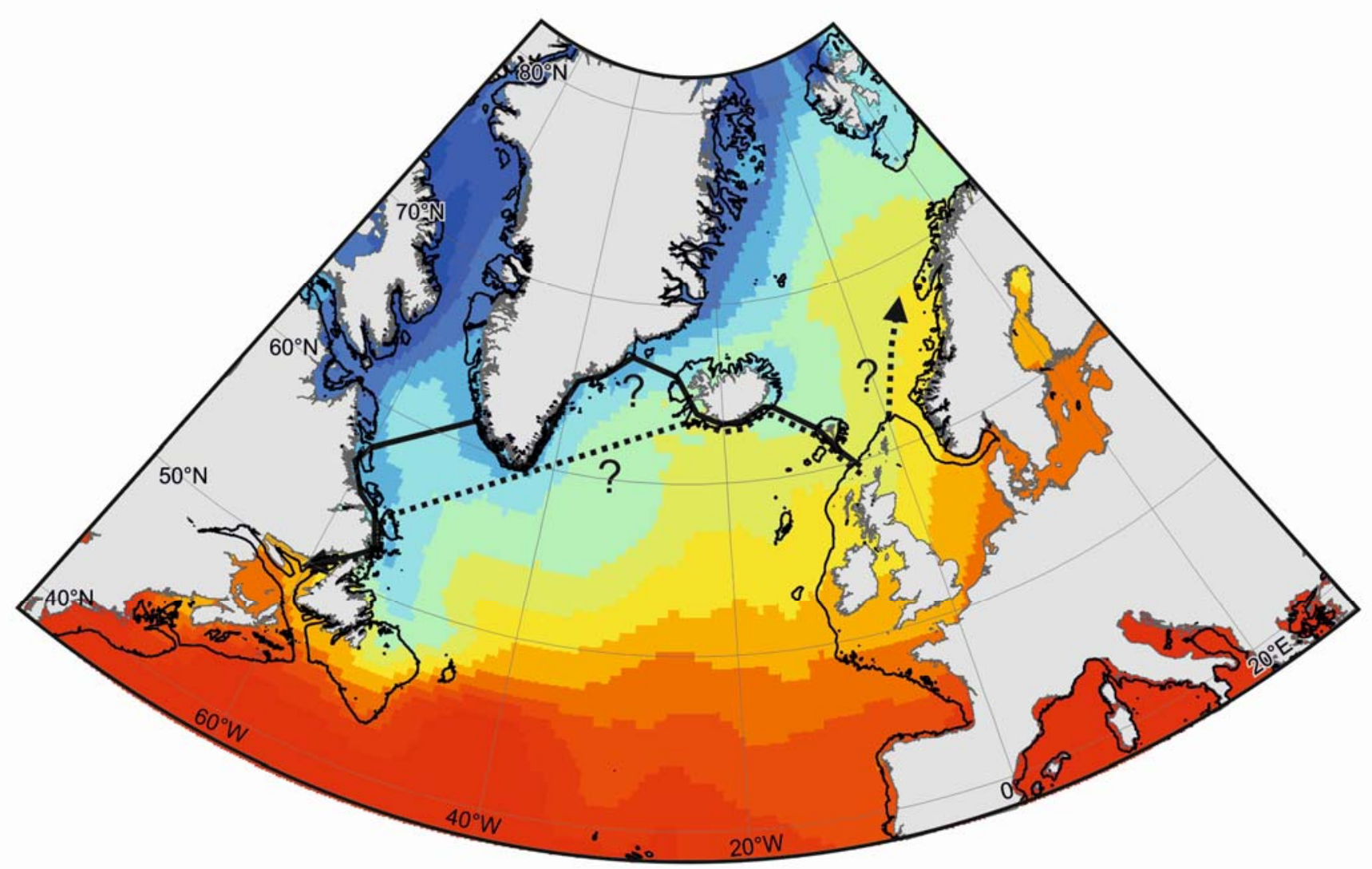

Figure 2. Predicted best migration routes of Sepia officinalis for the North Atlantic projected for 2300, under a mean summer sea surface temperatures (SST in ${ }^{\circ} \mathrm{C}$ ) obtained from HadGEM2-ES medium mitigation run: solid arrows for optional route with water temperatures above $7^{\circ} \mathrm{C}$ and dash lines for the route above $9^{\circ} \mathrm{C}$. The $200 \mathrm{~m}$ contour is also shown. See figure 1 for water temperatures for the corresponding colours. 